\title{
Diamond vs. square mesh codend in a multi-species trawl fishery of the western Mediterranean: effects on catch composition, yield, size selectivity and discards
}

\author{
Francesc Ordines ${ }^{1 \mathrm{a}}$, Enric Massutí1 ${ }^{1}$, Beatriz Guijarro ${ }^{1}$ and Ramon Mas $^{2}$ \\ 1 IEO- Centre Oceanogràfic de les Balears, Moll de Ponent s/n, 07015 Palma, Spain \\ 2 Direcció General de Pesca, Govern Illes Balears, Foners 10, 07100 Palma, Spain
}

Received 12 April 2006; Accepted 27 November 2006

\begin{abstract}
Selectivity studies usually describe the effects on target species, whereas information on by-catch and discards is scarce. Nevertheless, large quantities of undersized individuals and invertebrates are discarded in the Mediterranean multi-species bottom trawl fishery. The present work analyses the data from two surveys carried out on the shallow and deep continental shelf (50-78 m, and 147-189 m, respectively) off the Balearic Islands (western Mediterranean). In these surveys, the traditionally used $40 \mathrm{~mm}$ diamond mesh codend and an experimental square mesh codend were used under commercial conditions. Catch composition, yields, size selectivity of both target and by-catch species, and discards were compared between the two mesh types. The mean selection length $\left(L_{50}\right)$ clearly increased for most species when using square mesh, escaping many more individuals under their minimum landing size. Yield of Spicara smaris was significantly lower by using the square mesh, changing the composition of the retained catch. Escapement ratio and economic loss were significantly higher with square mesh, although economic loss was almost negligible for both meshes on the deep continental shelf. The use of square mesh significantly reduced the discards of algae in the shallow waters and fish on the deep continental shelf. The results confirmed that square mesh codend reduces the fishing pressure on small specimens as well as the impact of trawling on the ecosystem. These benefits would not lead to a reduction of the yields neither of the main target species, the fishes Merluccius merluccius, Mullus surmuletus, Zeus faber, and the cephalopods Loligo vulgaris and Octopus vulgaris, nor of the rest of commercial categories, except for Spicara smaris.
\end{abstract}

Key words: Bottom trawl / Multi-species fishery / Codend selectivity/ Diamond and square mesh / Discards / Balearic Islands

Résumé - Pêcherie plurispécifique méditerranéenne, comparaisons entre mailles de cul de chalut montées en losange et montées en carré : effets sur la composition des captures, des rendements, de la sélectivité des tailles et des rejets. Des études de sélectivité décrivent habituellement les effets sur une espèce-cible où les informations sur les captures accessoires et les rejets sont rares. Cependant, de grandes quantités de poissons et d'invertébrés de petites tailles sont rejetés dans les pêcheries plurispécifiques benthiques. Cette étude analyse les données de deux campagnes de pêche sur la plateau continental entre 50 et $78 \mathrm{~m}$, et en zone plus profonde entre 147 et $189 \mathrm{~m}$, respectivement, au large des îles Baléares. Durant ces campagnes, le chalut traditionnel, à mailles de $40 \mathrm{~mm}$, montées en losange et un chalut expérimental à mailles montées en carré ont été utilisés en conditions commerciales. La composition des captures, les rendements et la sélectivité des tailles, à la fois des espèces-cibles et de celles des rejets ont été comparés entre ces deux types de mailles. La taille moyenne de sélection $\left(L_{50}\right)$ augmente clairement pour la plupart des espèces en utilisant la maille carrée, laissant échapper davantage d'individus de taille inférieure à la taille autorisée pour les débarquements. Les rendements en Spicara smaris sont significativement inférieurs en utilisant la maille carrée, changeant la composition des captures retenues. La proportion des captures échappées et la perte économique sont significativement plus élevées avec la maille carrée bien que la perte économique soit presque négligeable pour les deux types de mailles en zones profondes du plateau continental. L'usage de maille carrée réduit significativement les rejets d'algues en eaux peu profondes, ainsi que les rejets de poissons en zones profondes du plateau continental. Les résultats confirment que les mailles de culs de chalut, montées en carré, réduisent la pression de pêche sur les petits individus ainsi que l'impact du chalutage sur l'écosystème. Ces avantages ne conduisent pas à une reduction des rendements ni ceux des principales espèces-cibles, les poissons Merluccius merluccius, Mullus surmuletus, Zeus faber, et les céphalopodes Loligo vulgaris and Octopus vulgaris, ni à ceux des autres catégories commerciales, à l'exception de Spicara smaris.

a Corresponding author: xisco.ordinas@ba.ieo.es 


\section{Introduction}

The Mediterranean bottom trawl fisheries are multi-species and exert a high fishing pressure on the younger and immature individuals (Caddy 1993). The poor selectivity of this fishery, with a minimum $40 \mathrm{~mm}$ diamond-shaped mesh in force, means that a large number of individuals from the target species are caught under their minimum landing size, which increases the mortality of these species, preventing any economic profit, and also decreases their yield per recruit. It also has indirect effects on other by-catch and non-commercial species, which contribute to the large quantities of fish and invertebrates discarded at sea, especially on the continental shelf (Carbonell et al. 1998; Sánchez et al. 2004). For these reasons, the improvement of trawl selectivity has been recommended by the General Fisheries Commission for the Mediterranean (GFCM), since it is considered to be a tool for reducing the impact of trawling on the ecosystems and improving the exploitation pattern of target species (GFCM 2001).

The codend mesh design has been established as an important factor determining the selectivity of a trawl (e.g. MacLennan 1992). The "traditional" diamond-shaped mesh in the codend stretches during the tow, hence reducing its selectivity when compared to "experimental" square mesh, which remains open (Robertson and Stewart 1988). Several studies have been conducted to assess the selectivity of these two types of mesh in the codends, both in the Atlantic (e.g. Campos et al. 2003) and the eastern Mediterranean (e.g. Petrakis and Stergiou 1997; Stergiou et al. 1997). In the western Mediterranean, the information on the performance of square-shaped mesh in the codend is limited to the trawl fishery on the shelf off the Ebro River delta and the Gulf of Lions (Bahamón et al. 2006; Mallol et al. 2001), and on the slope off the Balearic Islands (Guijarro and Massutí 2006). These studies have pointed out that the introduction of square-shaped mesh in the codend could be a useful management measure for consideration in the Mediterranean. However, these results can not be extrapolated for the whole area because trawl selectivity also depends, among other factors like gear, vessel or environment (Wileman et al. 1996), on the biocenoses (MacLennan 1992).

The continental shelf off Mallorca and Menorca (Balearic Islands) is narrow and mainly dominated by rocky, carbonate and gravel bottoms, in contrast to the terrigenous-dominated bottoms of the north-western Mediterranean (Canals and Ballesteros 1997). This factor, along with others such as fishing exploitation, could be the reason for certain differences related to discards, demersal resources and exploited sensitive habitats and vulnerable species observed between trawl fisheries in the insular and peninsular shelf grounds: (i) discards represent up to $70 \%$ of the captured biomass off Mallorca (Carbonell et al. 1998) and 35\% off the Catalan coast (Sánchez et al. 2004); (ii) of the two target red mullet species, Mullus surmuletus is more abundant than M. barbatus in insular assemblages although the opposite situation is found closer to the mainland (Massutí and Reñones 2005); (iii) according to these authors, grounds off the Balearic Islands have large quantities of non commercial species (red algae and echinoderms represent $55-75 \%$ of the biomass in the exploited communities) and maërl beds are found in some areas; (iv) the Balearic Islands show higher diversity and abundance of elasmobranchs compared to adjacent waters off the Iberian Peninsula (Massutí and Moranta 2003). Almost 40 trawlers undertake their fishing activity off Mallorca, the largest island of the Balearic Archipelago, where they operate on the continental shelf and slope. Although landings from the slope are mainly composed of a few decapod crustacean species (Guijarro and Massutí 2006), which have a higher economic value, the landings from the continental shelf are the most important in terms of biomass, since they are composed of a high number of fish species and some cephalopods.

The available works describing the effect of a change from diamond mesh to square mesh in the codend, are usually focused on target species. In the Mediterranean, only two works extend their analysis to the effects on catch composition, Stergiou et al. (1997) in the eastern Mediterranean, and Guijarro and Massutí (2006) for a slope bottom trawl fishery in the western Mediterranean. This information could be useful to develop a fisheries management in which the impact of fishing on the communities exploited is also taken in account, the so-called ecosystem approach. Our aim has been to contribute to the knowledge of selectivity by comparing under commercial conditions, the traditionally used diamond mesh codend with an experimental square mesh codend in the continental shelf bottom trawl fishery off the Balearic Islands (western Mediterranean). Hence, catch composition, yields, size selectivity of both target and by-catch species, and discards were compared between the two mesh types.

\section{Material and methods}

Sampling was conducted in traditional continental shelf fishing grounds off southern Mallorca (Balearic Islands, western Mediterranean; Fig. 1) during September-October 2002 and May-June 2003, on board the commercial bottom trawler F/V "Moralti Nou" (length 22 m; 59 grt; nominal engine power $365 \mathrm{hp}$ ) that operates in the area. Two different conventional polyethylene and polyamide "mallorquí" and "quadrat"-type bottom trawl nets were used, linked by steel and polypropylene sweeps to metallic and oval-shaped otter-boards. The trawl fleet on shallower and deeper shelf bottoms in the study area traditionally uses these gears, respectively.

Two codends of $40 \mathrm{~mm}$ nominal mesh size but with different mesh shape were assessed and each trawl type employed the covered codend method (Wileman et al. 1996). The codend cover was a diamond-shaped un-knotted polyethylene net with $20 \mathrm{~mm}$ stretched mesh attached directly to the funnel end of the net. In order to maintain a good flow of water and to avoid masking the codend meshes, the cover was 1.5 times wider and longer than the codends (Wileman et al. 1996).

A total of 24 trawl hauls were carried out during sunrise and followed routine commercial fishing procedures: 12 in 2002 at a depth of 50-78 m using the "mallorquí"-type net and 12 in 2003 at $147-189 \mathrm{~m}$ using the "quadrat"-type net. The duration of the hauls ranged between 1 and 2 hours and the towing speed between 2.6 and 3.6 knots. Each codend was used on the same gear and it was changed weekly, resulting in 6 hauls with each mesh and net type. After each haul, the crew and the scientific team sorted the catches in 

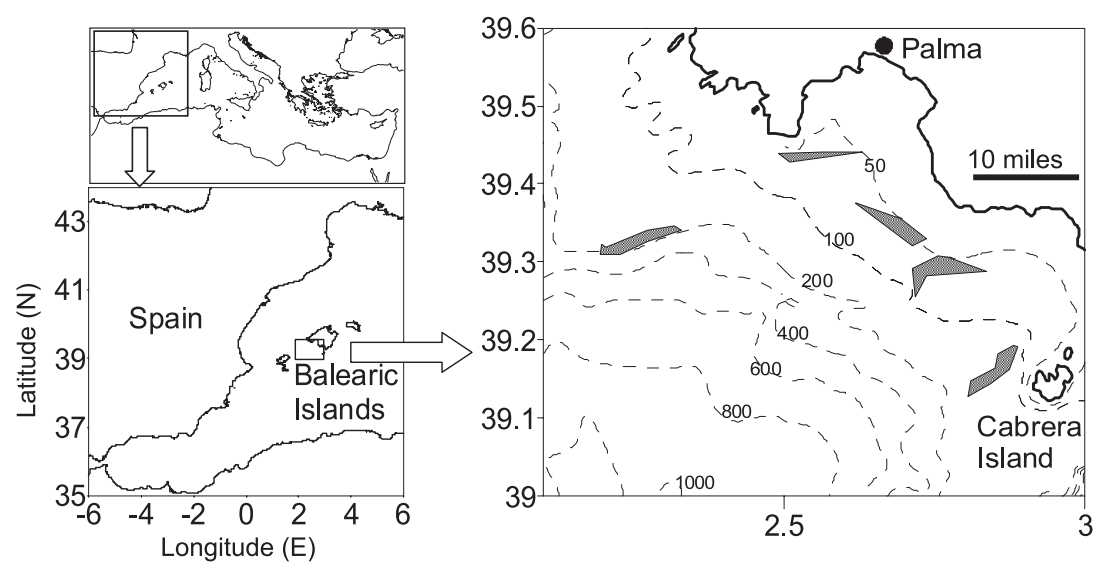

Fig. 1. Map showing the sampled areas off the southern coast of Mallorca (Balearic Islands, western Mediterranean). Dashed lines correspond to isobaths in meters.

the codend according to taxonomic and commercial categories (landings and discards), and then the categories were counted and weighed separately. Total fish length (TL) and cephalopod mantle length (ML) were measured for commercial species. Sub-sampling was done only to obtain the length distributions of Spicara smaris due to the great amount of individuals caught.

Trawl hauls were done on two different demersal resource associations that had been already described on the continental shelf off Mallorca (Massutí and Reñones 2005) at two different depth strata between 41 and $76 \mathrm{~m}$, and between 139 and $235 \mathrm{~m}$. Due to the differences in catch composition and assemblages exploited, the data analysis was done separately in each demersal resource association.

\section{Statistical analysis (RDA)}

Redundancy analysis (RDA) was used to investigate differences in catch composition $\left(\mathrm{kg} 30 \mathrm{~min}^{-1}\right)$ between mesh shapes of the most important commercial species retained in the codends. Monte Carlo free-distribution permutation based test was used to test the significance of the mesh shape effect. $\mathrm{Bi}$-plot diagrams were produced but, since there was only one environmental variable in the model, the second axis needed to be interpreted as a first residual axis (ter Braak and Smilauer 2002). Species appearing in less than 3 hauls were ommited from the analysis, as well as the species that were completely retained with both codend types (with the size of the individuals clearly larger than the mesh size), due to their variation in the yields should be completely unrelated to differences in selectivity of the codends. A RDA model followed with Monte Carlo test was also applied to test for overall differences in biomass $\left(\mathrm{kg} 30 \mathrm{~min}^{-1}\right)$ of the main taxonomic groups discarded.

Commercial yields for the most important species and catch categories, total discarded catch and discards of main taxonomic groups ( $\mathrm{kg} 30 \mathrm{~min}^{-1}$ retained in the codend), as well as the composition of discarded fishes were calculated for both SS and DS, and mesh shape. The following indexes were also calculated: (i) escapement ratio or proportion of the escaped catch, as $\mathrm{kg} 30 \mathrm{~min}^{-1}$, in relation to the total catch; (ii) Economic loss or proportion of the value of the escaped commercial species, as $€ 30 \mathrm{~min}^{-1}$, in relation to the total value; and (iii) economic efficiency or $€ \mathrm{~kg}^{-1}$ of the retained catch in relation to the total weight captured.

Gear saturation for both mesh shapes was analysed by attempting to fit a linear regression to the relationship between the escapement ratio and the retained catch by weight. It is hypothesised that the escapement ratio decreases with catch as the codend overfills, so a negative relationship would be expectable in the case of saturation.

A $t$-test was used to compare the commercial yields, discards, escapement ratio and economic indexes between mesh shapes. Prior to the use of the $t$-test, data were checked for the assumptions of normality and homogeneity of variance. When these assumptions were not met, data was log or square-root transformed (Underwood 1981). Proportional data were previously transformed to fit them to a normal distribution, according to the following expression:

$$
X=\arcsin \sqrt{\frac{X}{100}} .
$$

When the number of individuals in the cover was enough, size selectivity parameters were estimated, by mesh shape, for the most important species on the SS and DS. The retention probability of individuals that entered in the codend $\left(S_{L}\right)$ for each length class (L) was modelled for each single haul, using the logistic selection curve, which assumes that the data are binomially distributed:

$$
S_{\mathrm{L}}=\frac{e^{\left(S_{1}+S_{2} * \mathrm{~L}\right)}}{1+e^{\left(S_{1}+S_{2} * \mathrm{~L}\right)}} ;
$$

where $S_{1}$ and $S_{2}$ were the parameters to estimate. This logistic selection curve is one of the most recommended methods (e.g. Wileman et al. 1996). Mean selection length $\left(L_{50}\right.$, length at which the probability of being retained in the codend is $50 \%$ ) and selection range $\left(S R: L_{75}-L_{25}\right)$ were calculated from the expressions:

$$
L_{50}=-\frac{S_{1}}{S_{2}} \text { and } S R=\frac{2 \ln (3)}{S_{2}} .
$$


Fitting of the selection curves for individual hauls was carried out by maximizing the log-likelihood function, using SOLVER in MS-EXCEL (Tokai 1997). Goodness of fit was checked through a model deviance test and residual plots (Wileman et al. 1996). Mean selectivity curves and variance matrix of $S_{1}$ and $S_{2}$ estimates were calculated taking into account the interhaul variability by using the ECWeb (ConStat) software and following the methodology proposed by Fryer (1991). ECWeb software was also used to compare selection curves when individual haul fits were available for both kinds of mesh. The comparison was done by testing whether the differences between the two meshes for each parameter estimate $\left(S_{1}\right.$ and $\left.S_{2}\right)$ were significantly different from zero (Fryer 1991). Alternatively, when the number of individuals retained and escaped in single hauls was insufficient, logistic parameters were estimated from pooled data.

\section{Results}

The 24 trawl hauls carried out yielded $4205 \mathrm{~kg}$ of total landings, which represented an economic value of $9908 €$. The commercial species caught were comprised of 57 fishes, 8 cephalopods and 2 decapod crustaceans, which represented $92.4,7.5$ and $0.1 \%$ of the landings, respectively, in terms of biomass. The most important species were Spicara smaris (53\% of landed biomass), Mullus surmuletus (5\%), Loligo vulgaris (4.5\%), Trachurus mediterraneus (4\%), Pagellus acarne (4\%), Aspitrigla cuculus (3.5\%) and Zeus faber (3\%). From an economical point of view, the most important commercial species or catch categories were S. smaris $(25.5 \%)$, L. vulgaris (20\%), Z. faber $(16.5 \%)$, M. surmuletus $(10 \%)$ and the mixed fish category $(8 \%)$.

The most important commercial categories in both biomass and commercial value are summarized on Table 1. RDA on the catch biomass of the species present in those categories showed significant differences in the composition between mesh shapes on the shallow continental shelf (SS) (Fig. 2). The species that showed larger average abundances with diamond mesh were S. smaris, Serranus cabrilla and Octopus vulgaris, whereas L. vulgaris, Chelidonichthys lastoviza, Scorpaena scrofa, Trachinus draco, S. canicula, Pagellus erythrinus, $M$. surmuletus and $P$. acarne were more abundant with square mesh. No significant differences were found on the deeper continental shelf (DS). The commercial yield comparisons, between mesh shapes for the main species or catch categories, showed a few differences (Table 1). On the SS, catches of $S$. smaris were higher with diamond mesh, whereas catches of L. vulgaris were higher with square mesh. On the DS, catches of Lepidorhombus boscii and Z. faber were higher with square mesh, while for the octopus catch category the yields were higher with diamond mesh.

The escapement ratio and economic loss were significantly higher with square rather than diamond mesh (Fig. 3). The economic efficiency with square mesh was higher than with diamond mesh on the SS, whereas no differences were detected on the DS. No saturation was detected, because the relationships between the escapement ratio and the retained catch did not fit a linear regression: (i) on $\mathrm{SS}, p=0.26$ for diamond
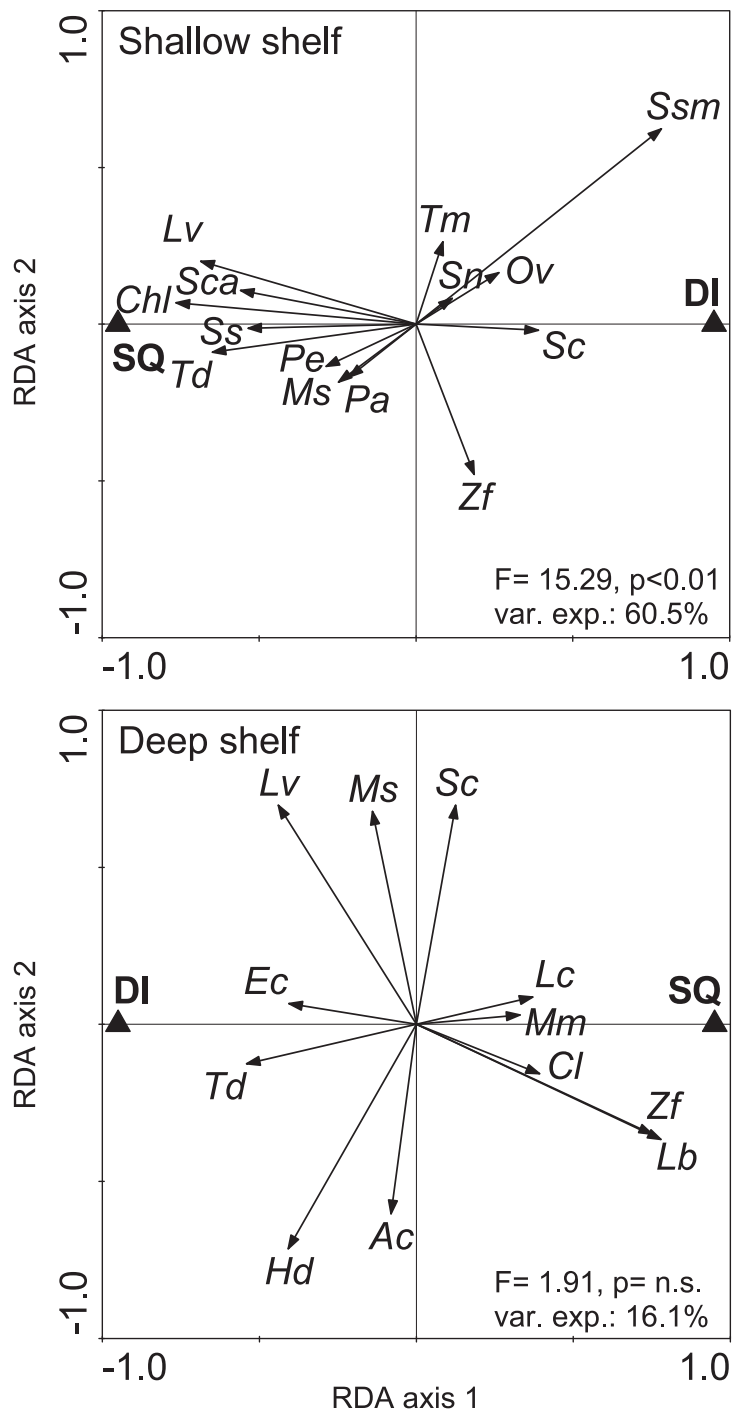

Fig. 2. Redundancy analysis (RDA) comparing catch biomass $\left(\mathrm{kg} 30 \mathrm{~min}^{-1}\right.$ ) composition, by mesh shape of the most important commercial species (see Table 2). Triangles are the centroids (groups of samples) of each mesh shape, and their perpendicular projection on the line overlaying a species arrow indicates the average biomass of that species for each mesh shape. DI and SQ are diamond and square mesh respectively; ns: non significant; var. exp.: variance explained by the model. Ac: Aspitrigla cuculus; Chl: Chelidonichthys lastoviza; $\mathrm{Cl}$ : Citharus linguatula; Ec: Eledone cirrhosa; Hd: Helicolenus dactylopterus; Lb: Lepidorhombus boscii; Lc: Lepidotrigla cavillone; Lv: Loligo vulgaris; Mm: Merluccius merluccius; Ms: Mullus surmuletus; Pa: Pagellus acarne; Pe: Pagellus erythrinus; Ov: Octopus vulgaris; Sn: Scorpaena notata; Sca: Scyliorhinus canicula; Ss: Scorpaena scrofa; Sc: Serranus cabrilla; Ssm: Spicara smaris; Td: Trachinus draco; Tm: Trachurus mediterraneus; Zf: Zeus faber.

mesh and $p=0.08$ for square mesh; (ii) on DS, $p=0.28$ for diamond mesh and $p=0.30$ for square mesh.

RDA model on the composition of the main taxonomic groups of discarded catches showed differences between mesh shape on the SS (variance explained $=46.8 \%, F=8.8$, $p<0.01$ ) and the DS (variance explained $=16.6 \%, F=2.0$, $p<0.05)$. By taxonomic groups, discards of algae on the 
Table 1. Catch biomass ( $\mathrm{kg} 30 \mathrm{~min}^{-1} \pm$ S.E.) of the most important commercial categories captured (comprising $>98 \%$ of the total commercial value, and $99 \%$ and $94 \%$ of the total biomass of commercial species for shallow and deep self respectively) and $t$-test results comparing between mesh shape yields (ns: non significant; *: $p<0.05$; **: $p<0.01$ ). Mean price of the species $\left(€ \mathrm{~kg}^{-1}\right)$ and percentage of the total commercial value $(\% \mathrm{CV})$ are also presented.

\begin{tabular}{|c|c|c|c|c|c|}
\hline & $\begin{array}{c}\text { Square } \\
\text { Mean } \pm \text { S.E. }\end{array}$ & $\begin{array}{c}\text { Diamond } \\
\text { Mean } \pm \text { S.E. }\end{array}$ & $\% \mathrm{CV}$ & Price & $t$-test \\
\hline \multicolumn{6}{|l|}{ Shallow shelf } \\
\hline \multicolumn{6}{|l|}{ Teleosts } \\
\hline Lophius spp. ${ }^{1}$ & $0.26 \pm 0.19$ & $0.74 \pm 0.24$ & 1.8 & 7.21 & ns \\
\hline Mixed fish ${ }^{2}$ & $12.50 \pm 1.98$ & $10.15 \pm 1.95$ & 11.7 & 2.08 & $\mathrm{~ns}$ \\
\hline Mullus surmuletus & $4.21 \pm 2.20$ & $2.43 \pm 0.74$ & 8.4 & 4.21 & ns \\
\hline Scorpaena scrofa & $0.45 \pm 0.19$ & $0.14 \pm 0.07$ & 1.5 & 12.17 & ns \\
\hline Spicara smaris & $20.68 \pm 4.44$ & $106.03 \pm 21.03$ & 37.1 & 1.34 & $* *$ \\
\hline Trachurus mediterraneus & $4.21 \pm 0.81$ & $4.69 \pm 1.68$ & 1.2 & 0.41 & ns \\
\hline Zeus faber & $0.40 \pm 0.20$ & $0.59 \pm 0.20$ & 3.2 & 12.24 & ns \\
\hline \multicolumn{6}{|l|}{ Elasmobranchs } \\
\hline Raja spp. ${ }^{3}$ & $0.36 \pm 0.13$ & $0.17 \pm 0.13$ & 2.2 & 1.33 & ns \\
\hline Scyliorhinus canicula & $1.83 \pm 0.45$ & $0.83 \pm 0.12$ & 0.8 & 0.76 & ns \\
\hline \multicolumn{6}{|l|}{ Cephalopods } \\
\hline Loligo vulgaris & $6.64 \pm 0.95$ & $3.37 \pm 0.55$ & 28.9 & 8.51 & $*$ \\
\hline Octopus $^{4}$ & $1.62 \pm 0.30$ & $2.17 \pm 0.48$ & 1.8 & 1.67 & ns \\
\hline \multicolumn{6}{|l|}{ Deep shelf } \\
\hline \multicolumn{6}{|l|}{ Teleosts } \\
\hline Lepidorhombus boscii & $0.61 \pm 0.04$ & $0.31 \pm 0.06$ & 2.7 & 4.84 & $* *$ \\
\hline Lophius spp. ${ }^{1}$ & $0.72 \pm 0.16$ & $0.96 \pm 0.13$ & 5.5 & 5.57 & ns \\
\hline Merluccius merluccius & $0.83 \pm 0.18$ & $0.62 \pm 0.08$ & 5.5 & 5.7 & ns \\
\hline Mixed fish ${ }^{5}$ & $8.74 \pm 0.49$ & $10.21 \pm 1.68$ & 9.9 & 1.78 & ns \\
\hline Mullus surmuletus & $1.66 \pm 0.44$ & $2.13 \pm 0.95$ & 12.2 & 5.19 & ns \\
\hline Scorpaena elongata & $0.17 \pm 0.13$ & $0.29 \pm 0.29$ & 2.1 & 13.22 & ns \\
\hline Zeus faber & $4.33 \pm 0.42$ & $1.95 \pm 0.51$ & 46.3 & 13.86 & $* *$ \\
\hline \multicolumn{6}{|l|}{ Elasmobranchs } \\
\hline Raja spp. ${ }^{6}$ & $4.40 \pm 0.99$ & $4.00 \pm 0.44$ & 5.2 & 1.41 & ns \\
\hline \multicolumn{6}{|l|}{ Cephalopods } \\
\hline Loligo vulgaris & $0.11 \pm 0.04$ & $0.35 \pm 0.16$ & 3.8 & 12.62 & ns \\
\hline Octopus $^{4}$ & $1.23 \pm 0.18$ & $1.95 \pm 0.25$ & 4.7 & 0.84 & $*$ \\
\hline
\end{tabular}

${ }^{1}$ Lophius budegassa and L. piscatorius.

${ }^{2}$ Chelidonichthys lastoviza, Serranus cabrilla, Trachinus draco, Pagellus erythrinus, Scorpaena notata, Pagellus acarne, Scorpaena porcus and Diplodus vulgaris.

${ }^{3}$ Raja miraletus and Raja radula.

${ }^{4}$ Octopus vulgaris and Eledone cirhosa.

${ }^{5}$ Serranus cabrilla, Trachinus draco, Aspitrigla cuculus, Lepidotrigla cavillone, Citharus linguatula and Helicolenus dactylopterus.

${ }^{6}$ Leucoraja naevus, Raja brachyura and Raja clavata.
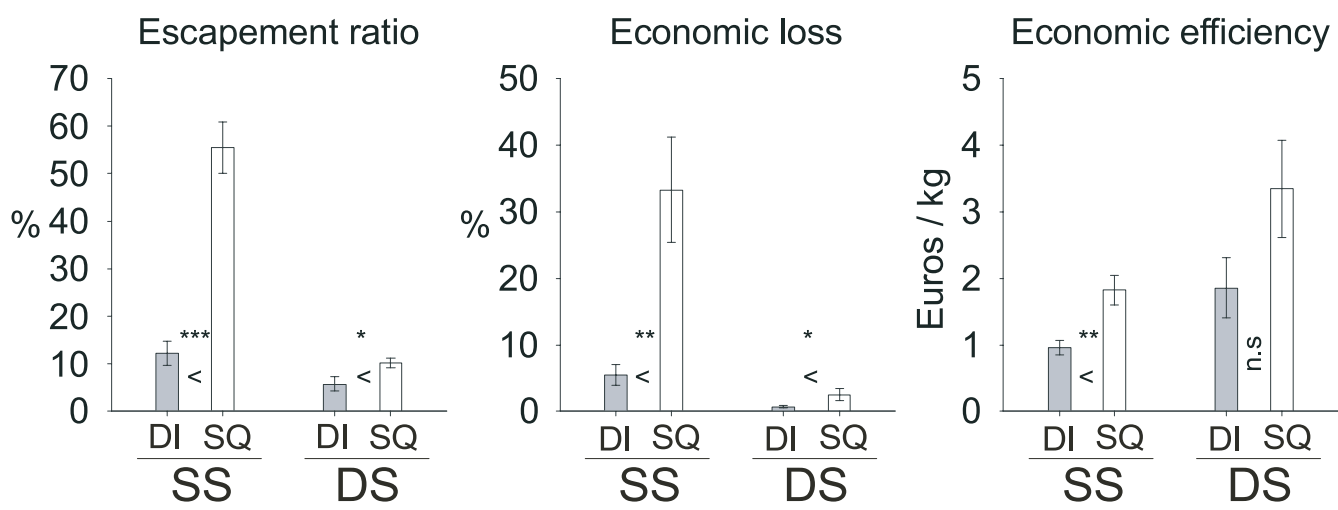

Fig. 3. Mean $( \pm$ S.E) escapement ratio, economic loss and economic efficiency for the shallow shelf (SS) and deep shelf (DS).; $t$-test results comparing mesh shape are also shown (n.s.: non significant differences; *: $p<0.05$; **: $p<0.01$; ***: $p<0.001$; DI: diamond mesh; SQ: square mesh). 

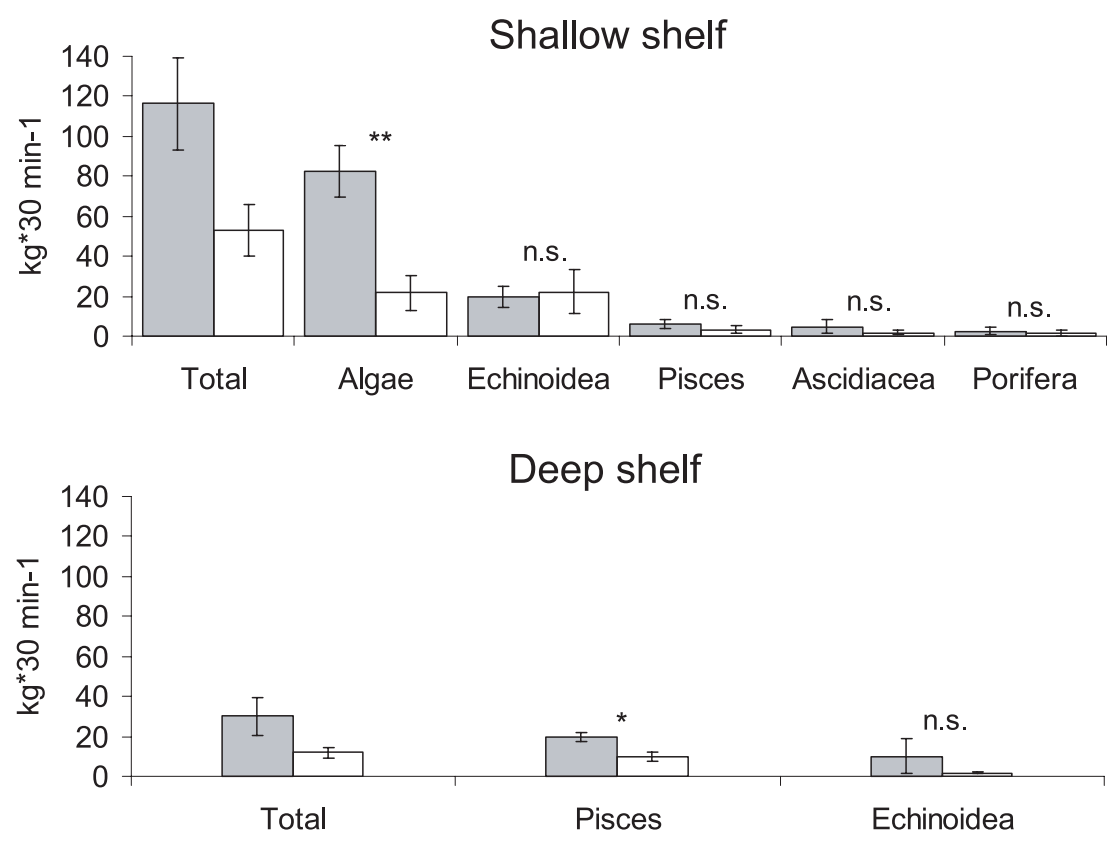

Fig. 4. Mean biomass ( $\mathrm{kg} 30 \mathrm{~min}^{-1} \pm$ S.E) for total discards and for principal taxa (representing $>99 \%$ of total weight discarded) for each mesh shape (white: square mesh; grey: diamond mesh). $t$-test results comparing mesh shape for each taxon are displayed (ns: non significant; $*: p<0.05$ and **: $p<0.01)$. On the SS, pisces discards were composed in $79.7 \%$ of non commercial species and $20.3 \%$ of commercial species (4.8\% Scorpaena notata, 4.3\% Raja miraletus, 3.4\% Trachurus mediterraneus and 7.8\% of other species with lower importance). On the DS, pisces discards were composed in $90.5 \%$ of non commercial species and $9.5 \%$ of commercial species (2.9\% Scyliorhinus canicula, $1.4 \%$ Lepidotrigla cavillone, $1.1 \%$ Aspitrigla cuculus and $4.1 \%$ of other species with lower importance).

SS, mainly soft red algae (89\%) and the green algae Codium bursa $(8 \%)$, were higher with diamond mesh $\left(t_{10}=-3.87\right.$; $p<0.01$ ), while no differences between mesh shape were observed for any other group (Fig. 4). This reduction was almost completely attributable to red algae (square mesh retained almost all the individuals of the green algae Codium bursa due to its size), and is remarkable since no differences were observed between meshes when summing codend and cover catches of red algae $\left(t_{10}=-0.92, p=0.48\right.$; with an average of 90 and $74 \mathrm{~kg} 30 \mathrm{~min}^{-1}$ for diamond and square, respectively). On the DS, the only differences between mesh shape were observed in the discards of fishes (Fig. 4), which were higher with diamond mesh $\left(t_{10}=-2.82 ; p<0.05\right)$. No differences between mesh shape were observed in the ratio between discarded commercial fishes and total discarded fishes: (i) on the SS $t_{10}=2.16, p=0.14$; (ii) on the DS $t_{10}=0.58, p=0.64$. The main species of discarded commercial fishes were Scorpaena notata, Raja miraletus and Trachurus mediterraneus on the SS, and Scyliorhinus canicula, Lepidotrigla cavillone and Aspitrigla cuculus on the DS. The most important non commercial fishes were Boops boops (63\%) and Serranus hepatus (10\%) on the SS, and Capros aper (40\%), Macrorhamphosus scolopax (32\%), Synchiropus phaeton (8\%) and Boops boops $(6 \%)$ on the DS.

Selectivity parameters and curves were calculated by mesh shape, taking into account between-haul variability or pooled data (Table 2, Fig. 5). In all species, there was a clear increase in the mean selection length from diamond to square mesh. Selection curves parameters obtained for T. mediterraneus, the one species in which individual haul fits where available for both meshes, were not significantly different depending on mesh shape $\left(t_{15}=-0.95\right.$ and $p=0.36$ for $S_{1} ; t_{15}=1.76$ and $p=0.10$ for $S_{2}$ ). Variance estimates were only presented when they were calculated from individual hauls (Table 2). Working with pooled data makes the variance estimates usually too small when compared to those obtained from individual haul data.

\section{Discussion}

Studies on selectivity improvement are especially important in the Mediterranean because of the overall problem of the high proportion of immature specimens (or for some target species, specimens smaller than their minimum landing size) in trawl catches (Stergiou et al. 1997; Sánchez et al. 2004). In addition, in some areas such as the Balearic Islands, the shelf trawl fishery shows a great number of discards, mainly composed of algae and invertebrates (Carbonell et al. 1998). In the present study we have compared, under commercial conditions, the selectivity of the "traditional" $40 \mathrm{~mm}$ diamond mesh codend and an "experimental" $40 \mathrm{~mm}$ square mesh codend in the trawl fishery carried out on the continental shelf off the Balearic Islands. To deal with the multi-species characteristic of this fishery, the comparison was focused not only on selectivity parameters of the target species, most of them already studied in other Mediterranean areas (Petrakis and Stergiou 1997; Bahamón et al. 2006), but also on catch composition, commercial yields and discards.

Differences in catch composition were observed between mesh shapes on the SS, mainly attributable to Spicara smaris, 

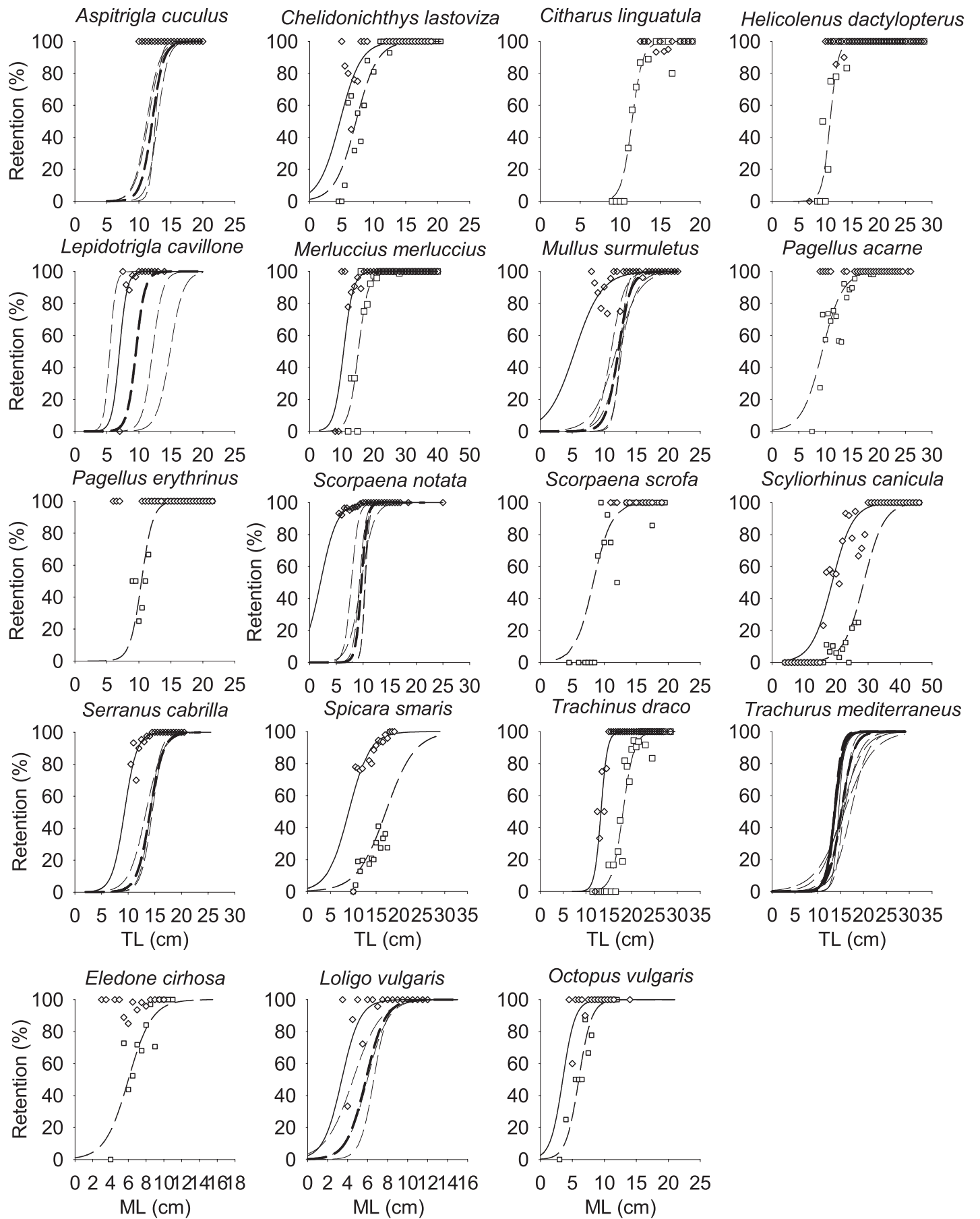

Fig. 5. Selection curves of species in Table 2 (solid line: diamond mesh; dashed line: square mesh; observed values are diamonds and squares for respective mesh shape). When between-haul variation was taken in account, thin curves are the logistic curves by haul, whereas thick lines represent mean logistic curves. Only one curve is presented when estimation have been done using pooled data. TL: total length; ML: cephalopod mantle length.

the most abundant species in terms of biomass. This species had a much higher scapement ratio with square mesh (up to $75 \%)$ than with diamond mesh (15\% approximately). This difference can also be on the basis of the differences observed in the overall escapement ratio and economic loss, whose values with square mesh were clearly higher than with diamond mesh. No other significant losses in commercial yields of the main target species or categories were observed when using square mesh. By contrast, some species such as Loligo vulgaris on the SS or Lepidorhombus boscii and Zeus faber on the DS showed the highest yields with square mesh. These differences can be attributed to the between-haul variability of yields rather than mesh shape, because the escapement ratios for these fishes were similar with both meshes (almost null), while for the 
Table 2. Selectivity parameters. $S_{1}$ and $S_{2}$ : selection curve parameters estimates; $L_{50}$ : mean selection length; $S R$ : $L_{75}-L_{25}$, selection range. When the selectivity parameters have been calculated by using the method of Fryer (1991), the variance matrix of $S_{1}$ and $S_{2}$ estimates $\left(R_{11}, R_{12}\right.$ and $R_{22}$ ) are presented, otherwise the selectivity parameters have been calculated from pooled data.

\begin{tabular}{|c|c|c|c|c|c|c|c|c|c|c|c|c|c|c|}
\hline \multirow[b]{2}{*}{ Species } & \multicolumn{7}{|c|}{ Diamond } & \multicolumn{7}{|c|}{ Square } \\
\hline & $S_{1}$ & $S_{2}$ & $L_{50}$ & $S R$ & $R_{11}$ & $R_{12}$ & $R_{22}$ & $S_{1}$ & $S_{2}$ & $L_{50}$ & $S R$ & $R_{11}$ & $R_{12}$ & $R_{22}$ \\
\hline \multicolumn{15}{|l|}{ Shallow shelf } \\
\hline C. lastoviza & -2.858 & 0.604 & 4.7 & 3.6 & & & & -4.394 & 0.605 & 7.3 & 3.6 & & & \\
\hline M. surmuletus & -1.703 & 0.377 & 4.5 & 5.8 & & & & -12.580 & 1.030 & 12.2 & 2.1 & 6.899 & -0.524 & 0.040 \\
\hline P. acarne & & & & & & & & -4.889 & 0.520 & 9.4 & 4.2 & & & \\
\hline P. erythrinus & & & & & & & & -11.575 & 1.110 & 10.4 & 2.0 & & & \\
\hline S. notata & -1.297 & 0.640 & 2.0 & 3.4 & & & & -17.870 & 1.837 & 9.7 & 1.2 & 19.100 & -1.681 & 0.152 \\
\hline S. scrofa & & & & & & & & -5.716 & 0.688 & 8.3 & 3.2 & & & \\
\hline S. cabrilla & -8.025 & 0.863 & 9.3 & 2.5 & & & & -11.420 & 0.808 & 14.1 & 2.7 & 5.024 & -0.332 & 0.022 \\
\hline S. smaris & -3.906 & 0.433 & 9.0 & 5.1 & & & & -5.423 & 0.316 & 17.1 & 6.9 & & & \\
\hline T. mediterraneus & -14.230 & 1.038 & 13.7 & 2.1 & 0.980 & -0.063 & 0.004 & -11.130 & 0.733 & 15.2 & 3.0 & 4.275 & -0.315 & 0.024 \\
\hline L. vulgaris & -3.752 & 1.099 & 3.4 & 2.0 & & & & -6.069 & 1.041 & 5.8 & 2.1 & 3.355 & -0.392 & 0.047 \\
\hline O. vulgaris & -3.641 & 1.038 & 3.5 & 2.1 & & & & -6.029 & 1.001 & 6.0 & 2.2 & & & \\
\hline \multicolumn{15}{|l|}{ Deep shelf } \\
\hline A. cuculus & & & & & & & & -13.530 & 1.117 & 12.1 & 2.0 & 3.789 & -0.254 & 0.017 \\
\hline C. linguatula & & & & & & & & -17.209 & 1.498 & 11.5 & 1.5 & & & \\
\hline H. dactylopterus & & & & & & & & -14.567 & 1.337 & 10.9 & 1.6 & & & \\
\hline L. cavillone & -11.803 & 1.694 & 7.0 & 1.3 & & & & -13.660 & 1.428 & 9.6 & 1.5 & 1.999 & -0.213 & 0.023 \\
\hline M. merluccius & -7.129 & 0.673 & 10.6 & 3.3 & & & & -10.029 & 1.659 & 15.2 & 3.3 & & & \\
\hline S. canicula & -5.785 & 0.308 & 18.8 & 7.1 & & & & -8.978 & 0.313 & 28.7 & 7.0 & & & \\
\hline T. draco & -18.958 & 1.426 & 13.3 & 1.5 & & & & -14.985 & 0.826 & 18.1 & 2.7 & & & \\
\hline E. cirhosa & -0.912 & 0.556 & 1.6 & 3.9 & & & & -4.561 & 0.757 & 6.0 & 2.9 & & & \\
\hline
\end{tabular}

cephalopod it was almost null with the diamond mesh and around $10 \%$ with square mesh. On the DS, escapement ratio and economic loss also showed differences between both meshes, but economic losses were almost negligible in both cases $(<1.5 \%)$, due to the relatively low value of small individuals.

The increase in escapement ratio with square mesh allowed a large quantity of biomass to escape, which would have otherwise been discarded. This is especially remarkable considering the large amounts of catches discarded on shelf bottoms (almost $120 \mathrm{~kg} 30 \mathrm{~min}^{-1}$ on the SS and $30 \mathrm{~kg} 30 \mathrm{~min}^{-1}$ on the DS). On the SS, discards were lower using square mesh, mainly due to a clear reduction of red algae (up to $60 \mathrm{~kg} 30 \mathrm{~min}^{-1}$ ), which also led to an increase of the economic efficiency. During the usual commercial fishing activity in the study area, most of the trawlers carry out a single haul on the SS, during the dawn, focussing successive ones on the DS or the slope crustacean fishery. Discarding is done during the navigation to the next haul location or during the next haul, and so, red algae are usually thrown on the DS or on the slope, where light intensity is not enough for the photosynthesis. Some of the predominant red algae species are free-living, which is the case for Peyssonnelia spp. (Ballesteros 1994) or rodolith species, while others like Osmundaria volubilis and Phyllophora crispa live attached to the substratum (Ballesteros 1992). Free-living species escaping through the mesh during the haul could return to their habitat and keep on growing. The fact that these algae could remain on the SS fishing grounds is important because they are a great source of primary production below $40 \mathrm{~m}$ depth (Ballesteros 1992), and also could play an important role on structuring the seafloor, even as detritic accumulations (Norkko et al. 2004). On the DS, a reduction of discarded fishes occurred (up to $10 \mathrm{~kg} 30 \mathrm{~min}^{-1}$; some of them commercial species), but no differences were observed for the echinoderms, which were the most abundant benthic group. In the Mediterranean, the effects of using square mesh in the codend on discards have been assessed only in the trawl shelf fishery of the Eastern Mediterranean (Stergiou et al. 1997), and on the slope of the western Mediterranean (Guijarro and Massutí 2006). Both works reported a reduction of discards, although for the last case, the reduction was found on the middle, but not on the upper slope.

The estimation of size selectivity parameters using Fryer's methodology was only suitable for some species (Mullus surmuletus, Scorpaena notata, Serranus cabrilla, Trachurus mediterraneus, Loligo vulgaris, Aspitrigla cuculus and Lepidotrigla cavillone) and only for square mesh. As in other studies in the Mediterranean, the low captures and the poor selectivity of the $40 \mathrm{~mm}$ diamond mesh prevented to escape enough specimens to apply this method (Petrakis and Stergiou 1997; Guijarro and Massutí 2006). Most of species showed a clearly higher $L_{50}$ with square mesh. Moreover, for many species the retentions were close to $100 \%$ when using diamond mesh, indicating poor selectivity. As for the previous aspects analysed, the biggest differences in $L_{50}$ between meshes were obtained for Spicara smaris, with an increment from 9 to $17 \mathrm{~cm}$. Although lower, increments in $L_{50}$ were also important for other target species such as M. surmuletus ( 5 to $12 \mathrm{~cm}$ ) and Merluccius merluccius (10 to $15 \mathrm{~cm}$ ). The estimated $L_{50}$ values for S. smaris, M. surmuletus and M. merluccius with the 
Table 3. Percentage of undersized individuals in relation to the total number of individuals retained and escaped $(\%<$ minimum landing size, MLS in $\mathrm{cm}$ ), and percentage of undersized individuals escaped in relation to the total number of undersized individuals (\%< MLS escaped) by mesh shape; $n$ : number of retained and escaped individuals.

\begin{tabular}{|c|c|c|c|c|c|c|c|}
\hline \multirow[b]{2}{*}{ Species } & \multirow[b]{2}{*}{$\begin{array}{l}\text { MLS } \\
(\mathrm{cm})\end{array}$} & \multicolumn{3}{|c|}{ Diamond } & \multicolumn{3}{|c|}{ Square } \\
\hline & & $n$ & $\%<\operatorname{MLS}$ & $\begin{array}{c}\%<\text { MLS } \\
\text { escaped }\end{array}$ & $n$ & $\%<\operatorname{MLS}$ & $\begin{array}{c}\%<\text { MLS } \\
\text { escaped }\end{array}$ \\
\hline Diplodus vulgaris & 15 & 85 & 3.5 & 0 & 200 & 67.0 & 0 \\
\hline Lepidorhombus boscii & 15 & 67 & 11.9 & 0 & 120 & 5.8 & 14.3 \\
\hline Lophius budegassa & 30 & 31 & 61.3 & 0 & 92 & 38.0 & 0 \\
\hline Lophius piscatorius & 30 & 16 & 68.2 & 0 & 4 & 25.0 & 0 \\
\hline Merluccius merluccius & 20 & 106 & 26.42 & 3.6 & 129 & 21.7 & 39.3 \\
\hline Mullus barbatus & 11 & 76 & 0 & & 112 & 0 & \\
\hline Mullus surmuletus & 11 & 686 & 13.9 & 14.6 & 2031 & 9.3 & 74.7 \\
\hline Pagellus acarne & 12 & 1024 & 1.7 & 0 & 2192 & 18.3 & 31.2 \\
\hline Pagellus erythrinus & 12 & 136 & 4.4 & 0 & 146 & 12.3 & 55.5 \\
\hline Spicara smaris & 11 & 97805 & 0.5 & 25.6 & 75828 & 0.8 & 96.9 \\
\hline Trachurus mediterraneus & 12 & 2848 & 5.1 & 35.6 & 3350 & 7.1 & 90.3 \\
\hline Trachurus trachurus & 12 & 51 & 19.6 & 89.8 & 6 & 50.0 & 0 \\
\hline
\end{tabular}

diamond mesh were clearly under the legal minimum landing size (MLS) in force ( 9 or 11 depending on the season, 15 and $20 \mathrm{~cm}$, respectively) and also under their length at first maturity (12, 15 and $30 \mathrm{~cm}$, respectively; Lozano-Cabo 1953; Reñones et al. 1995; Oliver 1993). By contrast, the $L_{50}$ values with the square mesh were larger than the MLS for S. smaris and $M$. surmuletus, although yet smaller for M. merluccius.

Improving the state of the resources by increasing $L_{50}$ depends upon a high survival rate of the escaped individuals. In this sense, the data available is scarce and even null in the case of Mediterranean trawl fisheries. In the north Atlantic, a study on gadoid fishes assessed the survival rates to be over $50 \%$ in the worst cases when testing different diamond mesh sizes (Sangster et al. 1996). To know the survival rates for Mediterranean fisheries and to determine the variations in this rates due to their multi-species nature is essential in order to assess the actual improvement that could be achieved with a change of mesh geometry.

The Balearic Islands have been reported to be one of the most diverse and abundant elasmobranches trawl assemblages in the western Mediterranean (Massutí and Moranta 2003), these species being particularly vulnerable to fishing exploitation (Stevens et al. 2000). Different responses to the change of mesh geometry were observed in this group. While for the flatfish skates (Raja spp.) no improvement in gear selectivity was detected (total retention with both meshes), the roundfish shark Scyliorhinus canicula showed a clear increase of $L_{50}$, from $19 \mathrm{~cm}$ to $29 \mathrm{~cm}$. This could be especially important on the DS, where juveniles of this species are abundant (Massutí and Moranta 2003) and those smaller than $35 \mathrm{~cm}$ are usually discarded (Carbonell et al. 2003).

One of the effects of overexploitation is a reduction of the size of the individuals, increasing the percentage of small specimens in the populations. For example, in the Gulf of Lions, individuals of Merluccius merluccius and Mullus barbatus below MLS represented up to 60 and $54 \%$ of the landed catch (Mallol et al. 2001). The change from diamond to square mesh has been reported as a good measure to reduce the percentage of undersized individuals for several species (Petrakis and Stergiou 1997; Campos et al. 2003; Bahamón et al. 2006).
This effect can also be observed in the present study (Table 3). However, mesh size was clearly not large enough to allow undersized individuals of species such as Lophius spp. to escape. This is a typical situation in multi-species fisheries, where species differing in body size and shape are present in the catch (e.g. Petrakis and Stergiou 1997).

Taking into account these results, the introduction of a $40 \mathrm{~mm}$ square mesh codend in the trawl fishery on the shelf off the Balearic Islands would reduce the fishing pressure on small specimens, leading to a subsequent improvement in the state of these resources. In addition, the increase in $L_{50}$ with square mesh would avoid some of the existing contradictions in the management of the Mediterranean trawl fishery, such as allowing the use of $40 \mathrm{~mm}$ diamond mesh, which leads to lower $L_{50}$ 's than the MLS. Square mesh would also reduce the large quantities of discards, and hence the impact of fishing exploitation on the ecosystems. This would be especially important if we consider that sensitive maërl beds are found in some coastal fishing grounds off the Balearic Islands (Canals and Ballesteros 1997; Massutí and Reñones 2005). These benefits could be reached without diminishing the commercial yields for the most important target species or catch categories, with the only exception of $S$. smaris.

Acknowledgements. We thank Joan Jesús Vaquero, Damià Gómez, Óscar Fernández, Manuel Salvà, Juan José Picó, and Vicente Sempere, the captain and crew of the FV "Moralti Nou", for their help during the surveys, and Biel Pomar, Maria Magdalena Guardiola, of the Centre Oceanogràfic de les Balears, for their assistance in both field and laboratory. We also thank Chris Rodgers for the English revision of the manuscript. The study was financed by the Spanish Ministry of Fisheries (RAI-AP-22/2001 and RAI-AP-6/2002).

\section{References}

Bahamon N., Sardà F., Suuronen P., 2006, Improvement of trawl selectivity in the NW Mediterranean demersal fishery by using a $40 \mathrm{~mm}$ square mesh codend. Fish. Res. 81, 15-25. 
Ballesteros E., 1992, Els fons rocosos profunds amb Osmundaria volubilis (Linné) R.E. Norris a les Balears. Boll. Soc. Hist. Nat. Balears 35, 33-49.

Ballesteros E., 1994, The Deep-water Peyssonnelia Beds from the Balearic Islands (Western Mediterranean). Pubbl. Staz. Zool. Napoli 15, 233-253.

Caddy J.F., 1993, Some future perspectives for assessment and management of Mediterranean fisheries. Scient. Mar. 57, 121-130.

Campos A., Fonseca P., Henriques V., 2003, Size selectivity for four fish species of the deep groundfish assemblage off the Portuguese southwest coast: evidence of mesh size, mesh configuration and cod end catch effects. Fish. Res. 63, 213-233.

Canals M., Ballesteros E., 1997, Production of carbonate particles by phytobenthic communities on the Mallorca-Menorca shelf, northwestern Mediterranean Sea. Deep-Sea Res. II. 44, 611-629.

Carbonell A., Martín P., De Ranieri S., WEDIS team, 1998, Discards of the western Mediterranean trawl fleets. Rapp. Comm. Int. Mer Médit. 35, 392-393.

Carbonell A., Alemany F., Merella P., Quetglas A., Román E., 2003, The by-catch of sharks in the western Mediterranean (Balearic Islands) trawl fishery. Fish. Res. 61, 7-18.

Fryer R.J., 1991, A model of between-haul variation in selectivity. ICES J. Mar. Sci. 48, 281-290.

GFCM, 2001, Report of the twenty-sixth session. GFCM Rep. pp. 26-27.

Guijarro B., Massutí E., 2006, Selectivity of diamond- and squaremesh codends in the deepwater crustacean trawl fishery off the Balearic Islands (western Mediterranean). ICES J. Mar. Sci. 63, 52-67.

Lozano-Cabo F., 1953, Monografía de los centracántidos mediterráneos con un estudio especial de la biometría, biología y anatomía de Spicara smaris (L.). Bol. Inst. Esp. Oceanogr. 59, 122.

MacLennan D.N. (editor), 1992, Fishing gear selectivity. Fish. Res. 13, 201-352.

Mallol S., Casadevall M., García E., 2001, Comparison of discarded, escaped and landed fish using diamond and square mesh codends. Rapp. Comm. Int. Mer Médit. 36, 296.

Massutí E., Moranta J., 2003, Demersal assemblages and depth distribution of elasmobranches from the continental shelf and slope trawling grounds off the Balearic Islands (western Mediterranean). ICES J. Mar. Sci. 60, 753-766.

Massutí E., Reñones O., 2005, Demersal resource assemblages in the trawl fishing grounds off the Balearic Islands (western Mediterranean). Scient. Mar. 69, 167-181.
Norkko A., Thrush S.F., Cummings V.J., Funnell G.A., Schwarz A.-M., Andrew N.L, Hawes I., 2004, Ecological role of Phyllophora antarctica drift accumulations in coastal softsediment communities of McMurdo Sound, Antarctica. Polar Biol. 27, 482-494.

Oliver P., 1993, Analysis of fluctuations observed in the trawl fleet landings of the Balearic Islands. Scient. Mar. 57, 219-227.

Petrakis G., Stergiou K.I., 1997, Size selectivity of diamond and square mesh codends for four commercial Mediterranean fish species. ICES J. Mar. Sci. 54, 13-23.

Reñones O., Massutí E., Morales-Nin B., 1995, Life history of red mullet (Mullus surmuletus) from the bottom trawl fishery off Mallorca Island (NW Mediterranean). Mar. Biol. 123, 411-419.

Robertson J.H.B., Stewart P.A.M., 1988, A comparison of size selection of haddock and whiting by square and diamond mesh codends. J. Cons. CIEM. 44, 148-161.

Sánchez P., Demestre M., Martín P., 2004, Characterisation of the discards generated by bottom trawling in the northwestern Mediterranean. Fish. Res. 67, 71-80.

Sangster G.I., Lehmann K., Breen M., 1996, Commercial fishing experiments to assess the survival of haddock and whiting after escape from four sizes of diamond mesh cod-ends. Fish. Res. 25, 323-345.

Stergiou K.I., Politou C.-Y., Christou E.D., Petrakis G., 1997, Selectivity experiments in the NE Mediterranean: the effect of trawl codend mesh size on species diversity and discards. ICES J. Mar. Sci. 54, 774-786.

Stevens J.D., Bonfil R., Dulvy N.K., Walker P.A., 2000, The effect of fishing on sharks, rays, and chimaeras (Chondrichthyans), and the implications for marine ecosystems. ICES J. Mar. Sci. 57, 476-494.

ter Braak C.J.F., Smilauer P., 2002, CANOCO reference manual and user's guide to Canoco for Windows: software for canonical community ordination (version 4.5). Microcomputer Power, NY, Ithaca.

Tokai T., 1997, Maximum likelihood parameter estimates of a mesh selectivity logistic model through SOLVER on MS-Excel. Bull. Jpn. Fish. Oceanogr. 61, 288-298.

Underwood A.J., 1981, Techniques of analysis of variance in experimental marine biology and ecology. Oceanogr. Mar. Biol. Ann. Rev. 19, 513-605.

Wileman D.A., Ferro R.S.T., Fonteyne R., Millar R.B. (eds.), 1996, Manual of methods of measuring the selectivity of towed fishing gears. ICES Coop. Res. Rep. 215. 